\title{
CORROSION RESISTANCE OF TI6AL4V TITANIUM ALLOY WITH MODIFIED SURFACES
}

Corrosion behaviour of biocompatible Ti6Al4V titanium alloy has been investigated by using electrochemical impedance spectroscopy in Hank's physiological solution for two modified states of titanium surface. On the basic of type and shape of Nyquist curves obtained from EIS measurements probable mechanisms of corrosion in a specific corrosion system are assigned.

\section{Introduction}

Titanium and its alloys are widely used as orthopaedic and dental implants. They belong among the best biocompatible materials due to their passivation characteristics and the stability of the passive films in a biological system [1,2].

This material has received widespread attention due to its low density, good strength, ductility corrosion resistance and biocompatibility. Titanium alloys have been clinically applied since 1970s when surgical implants were made with high-strength Ti6A14V alloy. The natural oxide layer on commercially pure titanium is composed of titanium oxide in different oxidation states $\left(\mathrm{TiO}_{2}, \mathrm{Ti}_{2} \mathrm{O}_{3}\right.$ and $\mathrm{TiO}$ ), while for Ti6 Al4V alloy, aluminium and vanadium are additionally present in oxidized form $\left(\mathrm{Al}_{2} \mathrm{O}_{3}\right.$ or $\left.\mathrm{V}_{2} \mathrm{O}_{5}\right)$. The passive films on the implant surface act as a barrier against the ion dissolution. Vanadium can alter the kinetics of the enzyme activity associated with the inflammatory response cells $[2,3]$.

With the degradation process metal ions are released, which accumulate in the tissue around the implant and also enter into the bloodstream. These ions may be responsible for wide range of undesirable effects. Various studies from the retrieved hip implants have established that the local reaction to particulate wear debris initiates the formation of a granulomatous tissue that ultimately invades the bone-implant interface and causes aseptic loosening. The combination of in vivo corrosion and cyclic loading may lead to the fracture of the implant, which is a serious clinical problem [4].

One of the biggest advantages of titanium alloys is their good corrosion resistance. The types of corrosion that have been observed on titanium and its alloys may be classified under the following general headings: general corrosion, crevice corrosion, stress corrosion cracking, anodic breakdown pitting, and galvanic corrosion.
General corrosion is characterised by an uniform attack over the entire exposed surface of metal. Titanium alloys are very resistant to almost all salt solution over the $\mathrm{pH}$ range of 3 to 11 ( $\mathrm{pH}$ of the physiological solution is about 7.4 [5]). The corrosion rate values for titanium alloys in variety of salt solution are generally less than $0.03 \mathrm{~mm} / \mathrm{yr}[6]$.

Titanium is mechanically and chemically suitable for use in orthopedic devices and dental implants, but lacks the bioactivity needed for bonding to bone tissue. Different surface treatments have been developed to improve the bioactivity and osteconductivity of titanium implants [7].

The main goal of presented investigation is evaluation of the corrosion resistance of the Ti6Al4V alloy surface after electroerosion treatment in Hank's solution.

\section{Experimental materials and methods}

Ti6Al4V alloy belongs to the most commonly used $(\alpha+\beta)$ titanium alloys. This type of Ti alloy is used as implant because of its good strength and ductility, being stronger and more resistant than both $\alpha$ or $\beta$ alloys and has an excellent corrosion resistance in biofluids [3].

Titanium and titanium alloys are nontoxic, well tolerated materials for human body. The implant must have safety stability (20 years) in the body fluid environment that can be in a fact considered as the water solutions of salt [8].

\subsection{Material preparation}

The medical grade TiAl6V4 titanium alloy made by forging was used for the study. The standardized chemical composition of this alloy is in Tab. 1 [8].

\footnotetext{
* Lenka Skublova, Viktor Skorik, Rastislava Mrazikova, Branislav Hadzima

Department of Materials Engineering, FME, University of Zilina, Slovakia, E-mail: lenka.skublova@fstroj.uniza.sk
} 
Standardized chemical composition (wt \%) of Ti6Al4V titanium alloy

\begin{tabular}{|c|c|c|c|c|c|c|c|}
\hline $\mathrm{N}$ & $\mathrm{C}$ & $\mathrm{H}$ & $\mathrm{Fe}$ & $\mathrm{O}$ & $\mathrm{Al}$ & $\mathrm{V}$ & $\mathrm{Ti}$ \\
\hline $\max$. & $\max$. & $\max$. & $\max$. & $\max$. & $5.50-$ & $3.50-$ & balance \\
0.05 & 0.08 & 0.15 & 0.4 & 0.2 & 6.75 & 4.50 & \\
\hline
\end{tabular}

The specimens were organized into two groups with different modified surface:

- set I - specimens prepared from the basic state of Ti6Al4V alloy,

- set II - specimens prepared of Ti6Al4V alloy with additional electro-erosion surface treatment (at electric discharge of 29 A).

\subsection{Microstructure analysis}

Microstructural investigation was done by an optical microscope Carl ZEISS AXIO Imager.A1m. The microstructure of Ti6A14V specimens (Fig.1) is a two-phase structure created by elongated

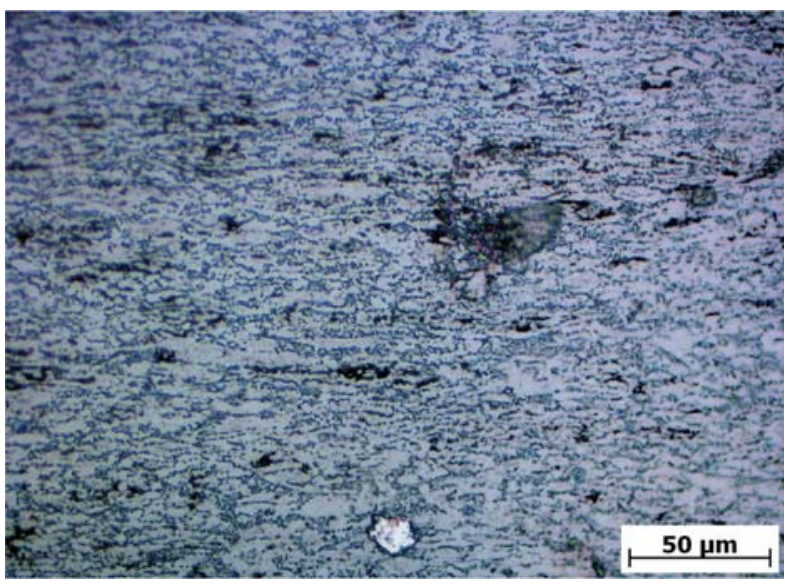

Fig. 1 Microstructure of Ti6Al4V alloy, etched $2 \mathrm{~mL} \mathrm{HF+8mL}$ $\mathrm{HNO}_{3}+90 \mathrm{~mL} \mathrm{H} \mathrm{O}_{2}$ [9]

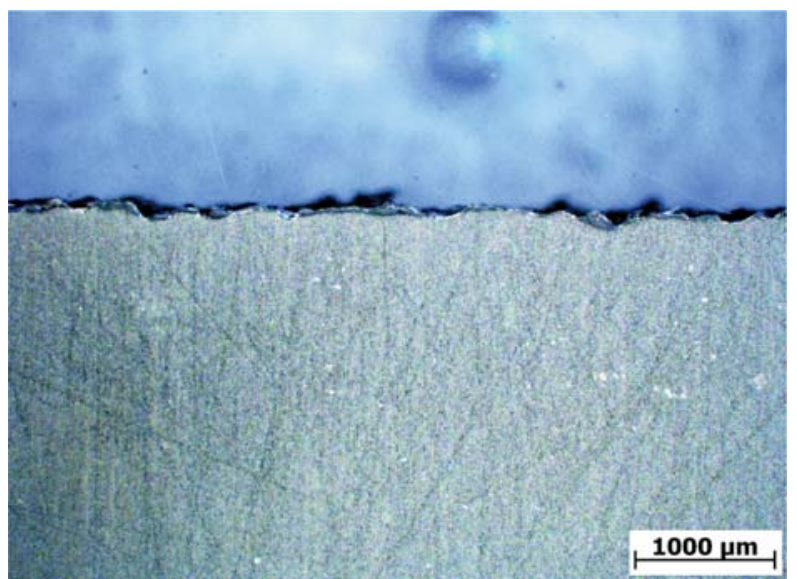

Fig. 2 Profile of electroeroded surface of Ti6Al4V alloy polyedric grains of $\alpha$ phase (bright grains with the average size of about $6.25 \mu \mathrm{m}$ ) and intergranular $\beta$ phase (dark/gray grains - 5 $\mu \mathrm{m})$. Detail of the surface profile after electroerosion is in Fig. 2. Average height of the profile at treated surface is about $190 \mu \mathrm{m}$.

\subsection{Corrosion testing}

The electrochemical tests were performed using electrochemical impedance spectroscopy (EIS) in Hank's physiological solution $\left(8 \mathrm{~g} / \mathrm{L} \mathrm{NaCl}, 0.4 \mathrm{~g} / 1 \mathrm{KCl}, 0.14 \mathrm{~g} / \mathrm{L} \mathrm{CaCl}_{2}, 0.1 \mathrm{~g} / \mathrm{L} \mathrm{MgSO}_{4} \cdot 7 \mathrm{H}_{2} \mathrm{O}\right.$, $0.06 \mathrm{~g} / \mathrm{L} \mathrm{KH}_{2} \mathrm{PO}_{4}, 0.05 \mathrm{~g} / \mathrm{L} \mathrm{NaH}{ }_{2} \mathrm{PO}_{4} \cdot \mathrm{H}_{2} \mathrm{O}$ a $1 \mathrm{~g} / \mathrm{L} \mathrm{D}$ - glucose [8]) at human body temperature $\left(37^{\circ} \mathrm{C}\right)$. This method allows establishing the value of polarization resistance of less conductive corrosion systems, for example when a passive layer with good adhesion is created on the metal surface. The polarization resistance $R_{p}$ is an electrochemical property characterizing the material properties in the certain environment. The higher value of $R_{p}$ represents better corrosion resistance of the material in corrosion environment. The electrochemical experiments were performed in a conventional three-electrode cell system with a calomel reference electrode and a platinum auxiliary electrode using Voltalab 10 corrosion measuring system with PGZ 100 measuring unit. The scheme of circuit connection and measuring principle is described in detail elsewhere [10].

The times for potential stabilization between the specimen and electrolyte, and the measuring frequencies are presented in Tab. 2. The amplitude of AC voltage was $20 \mathrm{mV}$. DC voltage component by which the specimen was polarized during testing was set to the measured value of free potential after stabilization.

Selected conditions of EIS measurements

Tab. 2

\begin{tabular}{|c|c|}
\hline Exposure time & Measured frequency \\
\hline 5 min. & $100 \mathrm{kHz}-5 \mathrm{mHz}$ \\
\hline 1 and $2 \mathrm{~h}$. & $100 \mathrm{kHz}-10 \mathrm{mHz}$ \\
\hline $4 \mathrm{~h}$. & $100 \mathrm{kHz}-15 \mathrm{mHz}$ \\
\hline 8 and $16 \mathrm{~h}$. & $100 \mathrm{kHz}-25 \mathrm{mHz}$ \\
\hline
\end{tabular}

\section{Results}

The results of electrochemical impedance spectroscopy measurements as Nyquist diagrams for Ti6Al4V alloy with basic surface and Ti6Al4V alloy with electroeroded surface are in Figs. 3 and 4 , respectively.

The procedure and method of polarization resistance calculating from Nyquist plots is described in [11]. The impedance spectrum for TiAl6V4 was fitted by EC-Lab Software V9.32 using equivalent circuit (Fig. 5) [12]. 


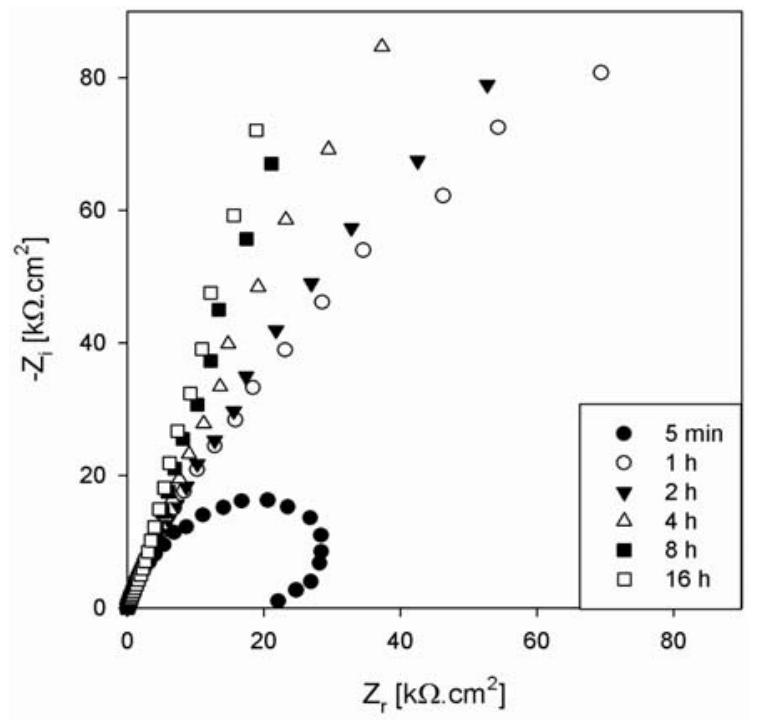

Fig. 3 Nyquist diagrams for basic state of Ti6Al4V alloy

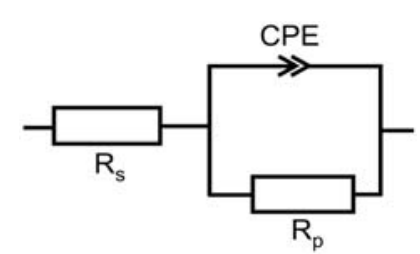

Fig. 5 Equivalent circuit for analysis of Nyquist plots, $R_{s}$ - resistance of testing solution, $R_{p}$ - polarization resistance, $C P E$ - constant phase element

The results of the Nyquist plots analysis are in Tab. 3 and Tab. 4 for basic and electroeroded surface of the Ti6Al4V alloy, respectively.

Electrochemical characteristic values for basic state

Tab. 3 of Ti6Al4V alloy in Hank's solution

\begin{tabular}{|c|c|c|c|c|}
\hline & $\begin{array}{c}R_{s} \\
{\left[\Omega . \mathrm{cm}^{2}\right]}\end{array}$ & $\begin{array}{c}C P E \\
{\left[10^{-6} \cdot \mathrm{F}^{-} \mathrm{sn}^{-1}\right]}\end{array}$ & $n$ & $\begin{array}{c}R_{p} \\
{\left[\Omega . \mathrm{cm}^{2}\right]}\end{array}$ \\
\hline $5 \mathrm{~min}$ & 35.43 & 29.77 & 0.845 & 132.141 \\
\hline $1 \mathrm{~h}$ & 29.96 & 21.26 & 0.8932 & 649.731 \\
\hline $2 \mathrm{~h}$ & 30.14 & 20.19 & 0.8655 & 768.760 \\
\hline $4 \mathrm{~h}$ & 30.21 & 20.19 & 0.8232 & $1,014.000$ \\
\hline $8 \mathrm{~h}$ & 28.44 & 19.32 & 0.8176 & $1,387.000$ \\
\hline $16 \mathrm{~h}$ & 25.09 & 18.26 & 0.8177 & $2,707.000$ \\
\hline
\end{tabular}

\section{Discussion}

The biggest production problem of a total hip replacement is not the way how to make an endoprothesis itself, but to find the

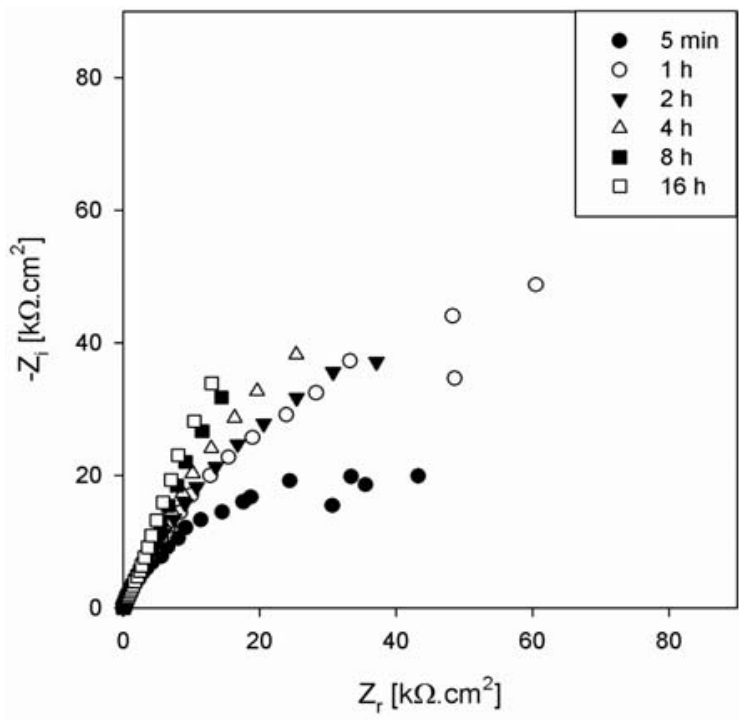

Fig. 4 Nyquist diagrams for electroeroded Ti6Al4V alloy

Electrochemical characteristics values for

Tab. 4 electroeroded Ti6A14V alloy in Hank's solution

\begin{tabular}{|c|c|c|c|c|}
\hline & $\begin{array}{c}R_{s} \\
{\left[\Omega . \mathrm{cm}^{2}\right]}\end{array}$ & $\begin{array}{c}C P E \\
{\left[10^{-6} \cdot \mathrm{F} \mathrm{sn}^{-1}\right]}\end{array}$ & $n$ & $\begin{array}{c}R_{p} \\
{\left[\Omega . \mathrm{cm}^{2}\right]}\end{array}$ \\
\hline $5 \mathrm{~min}$ & 36.52 & 44.32 & 0.7499 & 195.205 \\
\hline $1 \mathrm{~h}$ & 34.34 & 37.01 & 0.7744 & 392.568 \\
\hline $2 \mathrm{~h}$ & 40.61 & 32.61 & 0.7898 & 276.640 \\
\hline $4 \mathrm{~h}$ & 39.72 & 33.93 & 0.7793 & 408.300 \\
\hline $8 \mathrm{~h}$ & 39.73 & 32.72 & 0.7772 & 633.648 \\
\hline $16 \mathrm{~h}$ & 37.08 & 31.96 & 0.7759 & $1,189.000$ \\
\hline
\end{tabular}

best way of its fixation into human body. Nowadays, more methods are used. The endoprothesis with bioactive properties has the best prospect due to interacting between its surface and biological tissue. For example, porous surface of implants leads to tissue ingrowth. The investigation deals with the evaluation the corrosion resistance of the surface that had been treated by electro-erosive discharge. This kind of treatment can provide bioactive properties to the surface, but it also can cause small cracks due to stress that appears on the surface during treating process.

The analysis of the measured results shows that the polarization resistance $\left(R_{p}\right)$ of the interface titanium alloy - Hank's solution increases with exposure time (Fig. 6). The values of polarization resistance increase in case of using basic material (black columns in Fig. 6) and material with modified surface (gray columns in Fig. 6) as well. These values increase due to expansion of the passivation film on the surface that appears immediately after the investigated material is immersed into the experimental solution.

Dynamics of polarization resistance increase is affected by changes on the surface that are caused by modification of the surface 
during electrochemical erosive discharges. The $R_{p}$ values of the basic material increase uniformly. In a relatively short time, only 16-hour of exposure, $R_{p}$ value increases 20 -times, which is equal to the increase of the corrosion resistance. The measured values of the basic material surface are considered as reference because the modification of the implant surface is necessary for cell ingrowth. The analysis of curves measured on the electro-erosive modified surface shows that the $R_{p}$ values in case of electro-eroded material increase during exposure time more slowly than in case of basic material. At the time of exposure from 2 to 4 hours, it even stagnates.

The most likely reason of this polarization resistance behavior is less stability and greater inhomogenity of the passive layer due to the residual stresses on the surface after electro-erosive modification. This modification may also cause extra layer damage by creating cracks. Higher inhomogenity of the passive layer on the electro-eroded material is shown also by lower values of the parameter " $n$ " acquired by the analysis of the measured curves. During the 16-hour of exposure there was an increase of $R_{p}$ values, but compared to the basic material, it was relatively low (the reached value of $1.1 \mathrm{M} \Omega \cdot \mathrm{cm}^{2}$ ). Corrosion resistance of electro-eroded material decreases by more than half in comparison with the basic material.

The future investigation has to focus on an elimination of the deficiencies caused by surface modification. One possibility is to remove the internal stresses on the surface by heat treatment or chemical, possibly, electrochemical surface treatment.

\section{Conclusions}

On the basis of electrochemical impedance spectroscopy measurements we concluded the following results:

- The values of polarization resistance of basic and electroeroded material surface increase with the increase of exposure time. The $R_{p}$ values, in case of the basic material, increase after all

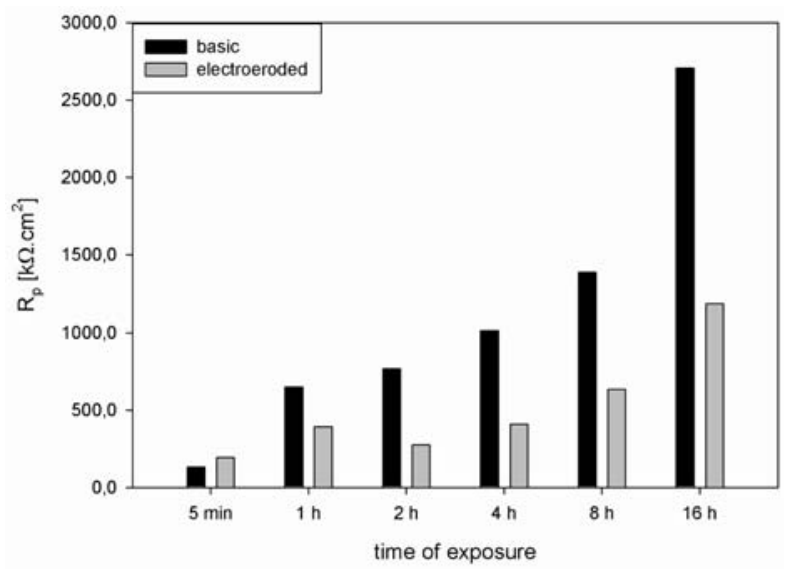

Fig. 6 Influence of exposure time of Ti6Al4V alloy in Hank's solution on polarization resistance for two types of different modified surface

exposure time. In the case of electroeroded surface, $R_{p}$ values increase between exposures of 5 minutes and 1 hour. During 14 hours of exposure, the $R_{p}$ values stagnate and after 8 and 16 hours of exposure time, they increase again.

- Comparison of the $R_{p}$ values shows that the electroeroded material reaches lower values of polarization resistance. In this case, the residual stresses generated on the surface during and just after the electric discharge reduced not only its mechanical properties, but also corrosion resistance. The polarization resistance of the basic material surface, without modifying the surface, reaches the twofold value $\left(2.7 \mathrm{M} \Omega . \mathrm{cm}^{2}\right)$ compared to electroeroded material surface $\left(1.1 \mathrm{M} \Omega . \mathrm{cm}^{2}\right)$.

\section{Acknowledgements}

This work was supported by the Science and Technology Assistance Agency under Contract No. APVV-LPP-0144-06. This work has been supported by the Scientific Grant Agency of the Ministry of Education and Slovak Academy of Sciences, grant No. $1 / 0203 / 08$.

\section{References}

[1] MIAO, S., WENG, W., LI, Z., CHENG, K., DU, P., SHEN, G., HAN, G.: Electrolytic Deposition of Octacalcium Phosphate/Collagen Composite Coating on Titanium Alloy. In: J Mater Sci: Mater Med 20, 2009, pp. 131-134.

[2] THAIR, L., KAMACHI MUDALI, U., RAJAGOPALAN, S., ASOKAMANI, R., RAJ, B.: Surface Characterization of Passive Film Formed on Nitrogen Ion Implanted Ti-6Al-4V and Ti-6Al-7Nb Alloys Using SIMS. In: Corrosion Science 45, 2003, pp. 1951-1967.

[3] VASilescu, E., DROB, P., RAduCANU, D., CinCA, I., MARECI, D., CALDERON MORENO, J.M., POPA, M., VASILESCU, C., MIRZA ROSCA, J.C.: Effect of Thermomechanical Processing on The Corrosion Resistance of Ti6Al4V Alloys in Biofluids. In: Corrosion Science 51, 2009, pp. 2885-2896.

[4] PALIWAL, M., ALLAN, D.G., FILIP, P.: Failure Analysis of Three Uncemented Titanium-Alloy Modular Total Hip Stems. In: Engineering Failure Analysis 17, 2010, pp. 1230-1238.

[5] NARAYANAN, R., KWON, T.-Y., KIM, K.-H.: Direct Nanocrystalline Hydroxyapatite Formation on Titanium from Ultrasonated Electrochemical Bath at Physiological pH. In: Materials Science and Engineering: C 28, 8, 2008, pp. 1265-1270.

[6] SHA, W., MALINOV, S.: Titanium Alloys: Modelling of Microstructure, Properties and Applications. Woodhead Publishing, Cambridge, UK, 2009, p. 592. 


\section{COMMNICOIIONS}

[7] LOPEZ-HEREDIA, M.A., LEGEAY, G., GAILlARD, C., LAYROLLE, P.: Radio Frequency Plasma Treatments on Titanium for Enhancement of Bioactivity. In: Acta Biomaterialia 4, 2008, pp. 1953-1962.

[8] SKUBlOVA, L., HADZIMA, B., BORBAS, L., VITOSOVA, M.: The Influence of Temperature on Corrosion Properties of Titanium and Stainless Steel Biomaterials. In: Materials Engineering 15, 2008, No. 4, pp. 18-22.

[9] PETZOW, G.: Metallographic Etching. 2 ${ }^{\text {nd }}$ Edition, ASM International, Ohio, 2001, p. 240.

[10] HADZIMA, B., LIPTAKOVA, T.: Zaklady elektrochemickej korozie kovov [Fundamentals of Electrochemical Corrosion of Metals]. 1st ed. EDIS ZU, Zilina, 2008, p. 116 (in Slovak).

[11] HADZIMA, B., SKORIK, V., BORBAS, L., OLAH, L.: Corrosion of Biocompatible AISI316 Stainless Steel in Physiological Solution. In.: Materials Engineering 15, 2008, No. 4, pp. 27-30.

[12] ORAZEM, M.E., TRIBOLLET, B.: Electrochemical Impedance Spectroscopy. New Jersey: John Willey and sons, USA, 2008, p. 523. 